\title{
MONITORING KEBIJAKAN PELAYANAN PARKIR DI TEPI JALAN UMUM DAERAH KOTA BENGKULU
}

\author{
Rekho Adriadi' ${ }^{1}$, Faizal Anwar ${ }^{2}$, Yogi Alfiansyah ${ }^{3}$ \\ Universitas Muhammadiyah Bengkulu, Bengkulu, 38226 \\ rekhoadriadi@umb.ac.id
}

\begin{abstract}
Abstrak
Tulisan ini mengkaji tentang pemantauan Kebijakan Pelayanan Parkir Di Tepi Jalan Umum Kota Bengkulu hasil Monitoring dari Analisis implementasi Kebijakan Pelayanan Parkir di Tepi Jalan Umum kota Bengkulu t. Dalam pelaksanaan kebijakan retribusi pelayanan parkir di kota Bengkulu ini secara standar dan prosedur sudah jelas namun dalam pelaksanaan dilapangan khususnya daerah Panorama masih terdapat pelanggaran. Sasaran dalam kebijakan ini sudah sesuai dengan Perda No. 07 Tahun 2011. Palaksanaan kebijakan parkir berbepengaruh dalam kondisi sosial masyarakat di kota Bengkulu dengan banyaknya titik parkir menjadi lahan penghasilan masyarakat kota Bengkulu. Akan tetapi dalam pencapaiannya masih ada ketidaksesuaian hasil pendapatan dan target dalam kebijakan ini yang dikarenakan pontensi parkir di kota Bengkulu yang masih rendah.
\end{abstract}

Kata Kunci: Kebijakan, Parkir, Retribusi

\begin{abstract}
This paper examines the Policy for Parking Services Policies on the Side of Public Roads in Bengkulu City as a result of the monitoring results from the analysis of the implementation of Parking Service Policies on Public Roadside of Bengkulu City In the implementation of the parking service retribution policy in Bengkulu city, the standards and procedures are clear, but in the field implementation, especially the Panorama area is still there. The targets in this policy are in accordance with Perda no. 07 of 2011. Implementation of parking policies that affect the social conditions of the people in the city of Bengkulu with the number of parking spots is the stage of the Bengkulu city community. However, during the crisis there was still a mismatch of income results and targets in this policy due to the low parking potential in the city of Bengkulu.
\end{abstract}

Keywords: Policy, Parking, Retribution

\section{PENDAHULUAN}

Negara Kesatuan Republik Indonesia merupakan negara kesatuan yang menganut asas desentralisasi, sebagaimana telah dijelaskan pada Amandemen Undang - Undang Dasar 1945 Pasal 18 (ayat) 2. Di dalam pasal tersebut juga dijelaskan bahwa Indonesia membagi daerahnya menjadi daerah provinsi, daerah kabupaten dan kota, yang mana daerah - 
daerah tersebut saling berhubungan erat dengan pemerintah pusat walaupun telah diberi kewenangan untuk mengurus daerahnya sendiri atau sering dikenal dengan Otonomi daerah.

Dasar hukum Otonomi daerah sendiri diatur dalam Undang - Undang No.23 Tahun 2014 tentang Pemerintahan Daerah. Salah satu faktor penggerak pelaksanaan Otonomi daerah adalah faktor sumber daya. Sumber daya mengacu pada manusia sebagai pembuat dan pelaksana program, dimana dalam sumber daya ini dibutuhkan orang - orang yang memiliki keahlian sesusai bidangnya. Selain itu, terdapat sumber daya berupa keuangan, di dalam keuangan daerah otonom harusdapat mengelola keuangan daerahnya dengan baik dan dapat mencari sumbersumber pendapatan untuk meningkatkan Pendapatan Asli Daerah (PAD) (Arenawati,2014:43). Pajak dan retribusi merupakan salah satu yang berpengaruh besar dalam peningkatan Pendapatan Asli Daerah (PAD). Didalam Undang-Undang Nomor 28 Tahun 2009 tentang Pajak daerah dan Retribusi daerah sudah menetapkan ketentuan-ketentuan pokok yang memberikan pedoman yang cukup rinci dalam menjelaskan prosedur Perpajakan dan Retribusi daerah.

Pemungutan Retribusi daerah didasarkan atas jasa pelayanan yang di berikan pemerintah daerah kepada perorangan atau kelompok/badan tertentu. Salah satu bentuk Retribusi daerah di kota Bengkulu adalah Retribusi Pelayanan Parkir di Tepi Jalan Umum. Retribusi parkir merupakan salah satu Pendapatan Asli Daerah (PAD) yang bersumber dari masyarakat, dimana pengelolanya adalah Dinas Perhubungan kota Bengkulu. Retribusi Pelayanan Parkir di Tepi jalan Umum di kota Bengkulu sendiri diatur dalam Peraturan Daerah Nomor 07 Tahun 2011.

Dalam dalam pelaksanaan kebijakan retribusi pelayanan parkir di kota Bengkulu masih banyak terjadi pelanggaran yang dilakukan, mulai dengan adanya penarikan Retribusi diluar ketetapan Perda seperti dengan ditariknya Retribusi di depan ruko, selain itu tidak adanya karcis parkir menjadi masalah yang bersifat vital dikarenakan karcis tersebut dapat di ketahui berapa retribusi yang didapat dari pelayanan parkir. Dari data Dinas Perhubungan kota Bengkulu pada tahun 2016 kota Bengkulu 
memiliki 526 titik parkir dari 12 tempat zona parkir. Pada pelaksanaannya banyak sekali masalah yang ditemukan, selain dari kutipan berita di atas masalah lainnya adalah banyaknya juru parkir yang tidak mengenakan tanda pengenal hal tersebut terindikasi kemungkinan juru parkir liar. Selain itu, juru parkir tidak menarik tarif parkir kepada Angkutan Kota yang parkir di tepi wilayah kota Bengkulu.

Analisa Monitoring Kebijakan Pelayanan Parkir di Tepi Jalan Umum ini menggunakan konsep pemantauan kebijakan dari William N. Dunn yang memiliki empat fungsi, yaitu ekplanasi, kepatuhan, audit dan akunting dengan jenis pendekatan pemeriksaan sosial. (1) Eksplanasi, evaluator dapat mengidentifikasi masalah, kondisi, dan aktor pendukung keberhasilan dan kegagalan kebijakan; (2) Kepatuhan, melalui pemantauan dapat diketahui apakah tindakan para pelaku baik birokrasi maupun pelaku lainnya, sesuai dengan standar prosedur yang ditetapkan kebijakan; (3) Audit, melalui pemantauan dapat diketahui apakah output benar - benar sampai kepada kelompok sasaran kebijakan, atau ada kebocoran dan penyimpangan; (4) Akunting, memalui pemantauan dapat di ketahui apakah akibat ekonomi dari kebijakan teresebut. Melalui pemantauan dapat digambarkan realitas pelaksanaan program. Pendekatan pemeriksaan sosial yang dikemukakan William N. Dunn di nilai cocok untuk menganalisis penelitian ini, karena pemeriksaan sosial secara eksplisit memantau hubungan antara masukan, proses dan pengeluran dan dampak dari kebijakan tersebut.

Berdasarkan uraian singkat tersebut, maka tulisan ini bertujuan membahas persoalan tersebut dengan mengajukan pertanyaan utama yaitu: Bagaimanakah implementasi Kebijakan Pelayanan Parkir di Tepi Jalan Umum kota Bengkulu?. Untuk mendapatkan temuan dari pertanyaan tersebut metode pengumpulan data dalam penelitian ini dengan pendekatan deskriptif analisis dengan metose kualitatif, dengan memfokusakan pada: yaitu ekplanasi, kepatuhan, audit dan akunting dengan jenis pendekatan pemeriksaan sosial. Sumber data yang digunakan berupa data yang diperoleh melalui pengumpulan data dari pihak Dinas Perhubungan Kota 
Bengkulu, juru parkir wilayah kota Bengkulu, hasil riset serta pemberitaan media massa.

\section{METODE PENELITIAN}

Penelitian ini menggunakan metode Deskriptif analisis dengan pendekatatan kualitatif. Informan dalam penelitian ini adalah pegawai Dinas Perhubungan Kota Bengkulu, juru parkir dan Masyarakat pengguna jasa pelayanan parkir. Jenis data yang digunaka adalah data yang berbentuk angka dan data berbentuk tulisan atau kata-kata. Sumber data dalam penelitian ini ada dua jenis yang pertama adalah data primer yang berasal dari wawancara, dan data sekunder yang berasal dari observasi, dokumentasi dan studi pustaka dan lain-lain. Metode pengumpulan data yang digunakan adalah wawancara, observasi, dokumentasi dan studi pustaka. Selanjutnya metode analisis data yang digunkan adalah yang reduksi data, kemudian data pilah dan di olah lalu disajikan yang pada akhirnya ditarik kesimpulan atas jawaban-jawaban yang diperoleh dari informan. Kualitas atau keabsahan data menggunakan triangulasi dengan membandingkan hasil wawancara antara informan satu dengan informan lainnya dan juga dengan dokumen yang berkaitan dengan penelitian.

\section{HASIL DAN PEMBAHASAN}

Dinas Perhubungan melaksanakan tugasnya dalam kepengelolaan pemungutan retribusi parkir dimulai sejak adanya berita acara serah terima pengelolaan parkir dari Dispenda kota Bengkulu ke Dinas Perhubungan, Kota Bengkulu Nomor : 97/01/TU/Dispenda/2008 Tanggal 14 Januari 2008. Yang selanjutnya pada tahun 2011 di terbitkanlah Peraturan Daerah Nomor 07 tahun 2011. Berdasarkan Perda Nomor 07 Tahun 2011 tentang retribusi parkir di tepi jalan, tertera pada pasal 3 yaitu menjelaskan bahwa objek dari retribusi adalah penyediaan pelayanan parkir di tepi jalan umum yang ditentukan oleh Pemerintah Kota Bengkulu.Dinas Perhubungan kota Bengkulu memliki persyaratan yang harus dipenuhi oleh seorang petugas parkir atau juru parkir selaku pihak yang berugas untuk menarik retribusi 
parkir yang ada di lapangan. Persyaratan tersebut adalah dengan Surat Perintah Tugas (SPT), Selain Surat Perintah Tugas (SPT) persyaratan lain yang harus di penuhi seorang juru parkir resmi dari Dinas Perhubungan Kota Bengkulu. Persyaratan tersebut adalah perlengkapan lapangan berupa kartu tanda pengenal , rompi, peluit dan karcis parkir yang di keluarkan oleh Pihak Dinas Perhubungan (Hasil Penelitian 2018). Berikut adalah standard dan prosedur kebijakan retribusi pelayanan parkir tepi jalan umum yang dikeluarkan oleh Dinas Perhubungan kota Bengkulu : 
Tabel 1

Standar Pelayanan Izin Parkir

\begin{tabular}{|c|c|c|}
\hline No & Komponen & Uraian \\
\hline 1 & Produk Pelayanan & Produk Pelayanan \\
\hline \multirow[t]{11}{*}{2} & Persyaratan Pelayanan & A. Pengurusan SPT Titik Parkir Baru \\
\hline & & 1. Permohonan \\
\hline & & 2. Fotocopi KTP \\
\hline & & 3. Pas Foto $3 \times 4=3$ lembar \\
\hline & & 4. Izin Pemilik Usaha / ruko \\
\hline & & 5. Map Lobang Plastik 1 buah \\
\hline & & 6. Pernyataan \\
\hline & & $\begin{array}{l}\text { B. Pengurusan SPT Perpanjangan Titik } \\
\text { Parkir }\end{array}$ \\
\hline & & 1. Fotokopi KTP \\
\hline & & 2. Pas Foto $3 x_{4}=2$ Lembar \\
\hline & & 3. Bukti Setoran Parkir Bulan Berjalan \\
\hline \multirow[t]{8}{*}{3} & Sistem Mekanisme \& & A. Pengurusan SPT Titik Parkir Baru \\
\hline & & 1. Pemohon \\
\hline & & 2. Mengisi Formulir Permohonan \\
\hline & & $\begin{array}{l}\text { 3. Pemeriksaan Administrasi } \\
\text { Persyaratan }\end{array}$ \\
\hline & & 4. Survey Lapangan Titik Parkir \\
\hline & & 5. Penentuan Retribusi Parkir \\
\hline & & $\begin{array}{l}\text { 6. Penyetoran Retribusi Pemilik SPT ke } \\
\text { Bank }\end{array}$ \\
\hline & & 7. SPT Selesai \\
\hline
\end{tabular}

B. Pengurusan SPT Perpanjangan Titik Parkir

1. Pemohon

2. Pemeriksaan Persyaratan

3. Penyetoran Retribusi ke Bank

4. SPT Selesai

\begin{tabular}{lll}
\hline 4 & $\begin{array}{l}\text { Jangka waktu } \\
\text { Penyelesaian }\end{array}$ & 1. Pembutan SPT Baru $2 \mathrm{~s} / \mathrm{d} 3$ Hari kerja \\
\hline & 2. Perpanjangan SPT Satu hari kerja
\end{tabular}

5 Pembiayaan Sesuai yang Tertuang di Pasal 11 Perda

No. 07 Tahun 2011

6 Mekanisme Pengaduan Meneriama Layanan Pelaporan

Perpakiran Kota Bengkulu

1. Petugas penagduan Ka. UPTD Parkir Kota Bengkulu

2. Di proses selama 1 Hari kerja

Sumber : Dinas Perhubungan kota Bengkulu 2020

Dari penyajian tabel diatas tertera standar dan prosedur kebijakan pelayanan parkir di tepi jalan umum kota Bengkulu yang berlandaskan Perda 
No. 07 Tahun 2011 Selanjutnya dari tabel 1 dapat dijelaskan kembali alur pembuatan surat perintah tugas (SPT) parkir berdasarkan standar dan prosedur ke dalam skema berikut:

Gambar 1

Pengajuan Petugas dan Lahan Parkir

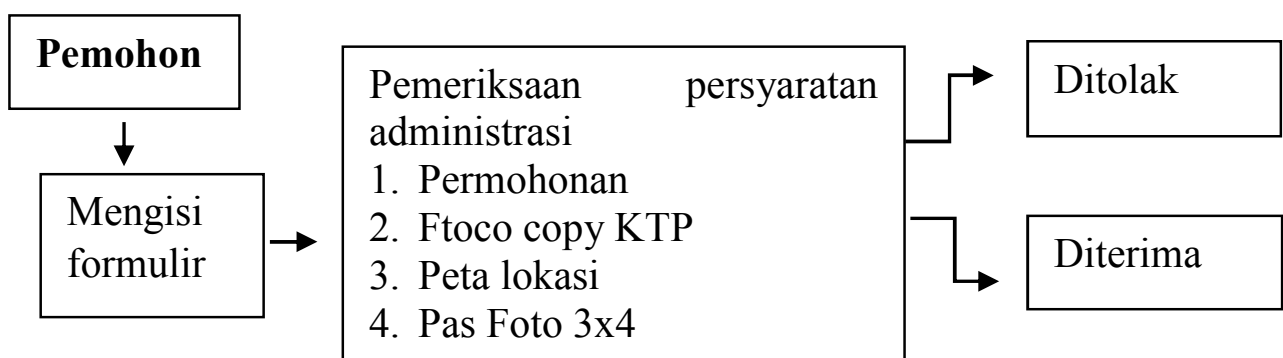

Sumber: Dinas Perhubungan Kota Bengkulu 2020

Apabila pengajuaan diterima maka Dinas Perhubungan akan melakukan survey di lokasi parkir yang telah diajukan. Survey tersebut merupakan hal menentukan ajauan lahan parkir diterim atau tidak oleh Dinas Perhubungan Kota Bengkulu. Alur survey lahan Parkir berdasarkan standar dan prosedur dijelaskan kedalam skema berikut ini:

Gambar 2

Alur Survey Lahan Parkir

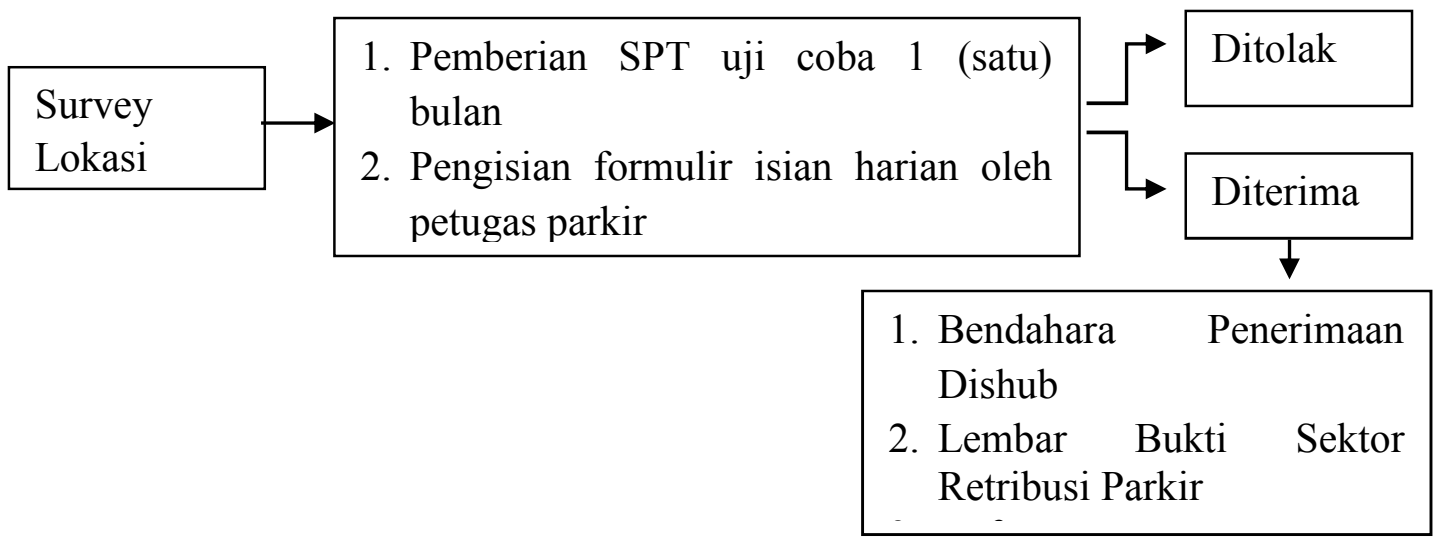

Sumber: Dinas Perhubungan Kota Bengkulu 2020

Setelah survey dilakukan maka Dinas Perhubungan mengeluarkan surat perintah tugas (SPT) percobaan selama satu (1) bulan dan karcis parkir. Pemilik surat perintah tugas (SPT) juga harus mengisi formulir harian yang diberikan oleh Dinas Perhubungan. Apabila lahan parkir 
diterima maka Dinas Perhubungan kota Bengkulu menetapkan besaran setoran parkir dan surat perintah tugas (SPT) untuk lokasi tersebut.

Surat perintah tugas (SPT) dan masa berlakunya sudah habis maka dapat diperpanjang. Skema alur perpanjangan surat perintah tugas (SPT) berdasarkan standar dan prosedur yang terdapat pada gambar 3, adalah sebagai berikut:

\section{Gambar 3}

Pengajuan Perpanjangan Surat Perintah Tugas Parkir

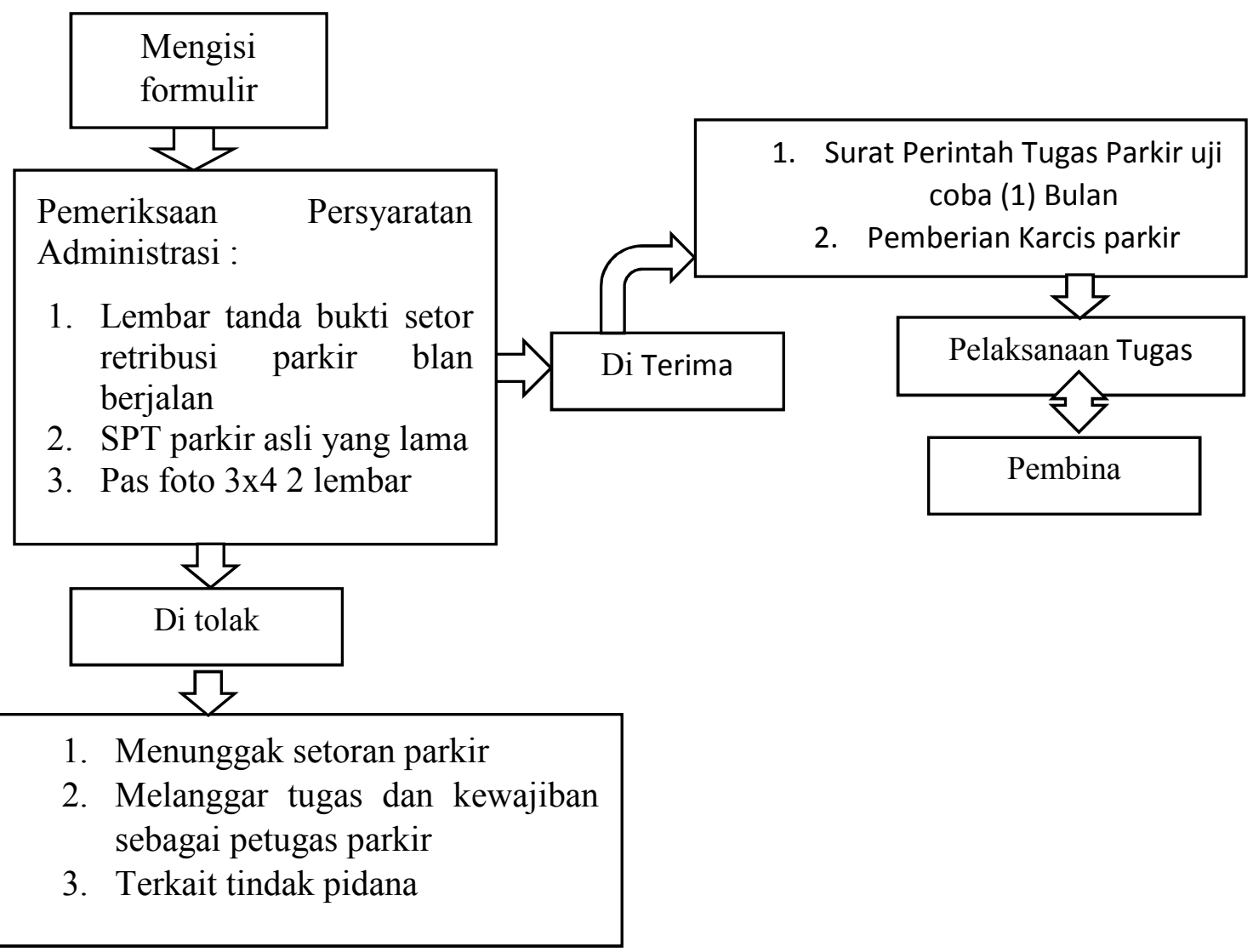

Sumber: Dinas Perhubungan Kota Bengkulu 2020

Selain standard dan prosedur kebijakan parkir, Pelaksanaan juga terfokus pada ruas atau wilayah titik parkir yang ada di kota Bengkulu. Wilayah parkir menentukan jumlah besaran pendapatan daerah dari sektor parkir terebut. Dari hasil pemantuan peneliti jumlah titik parkir di kota Bengkulu mencapai 652 titik parkir (Data Dinas Perhubungan Kota Bengkulu 2019) dan jumlah titik tersebut akan terus bertambah seiring dengan adanya potensi wilyah parkir yang ada di kota Bengkulu. Berikut adalah wilayah dan pendapatan perbulan retrubusi pelayanan parkir di kota Bengkulu: 
Tabel 2

Batas Area Pemungutan dan Pendapatan Retribusi Parkir Kota Bengkulu

\begin{tabular}{|c|c|c|c|c|}
\hline No & $\begin{array}{l}\text { Kelo } \\
\text { mpok } \\
\text { Zona } \\
\text { si }\end{array}$ & Batas Area dan Nama-Nama Jalan & $\underset{\text { humla }}{\text { Titik }}$ & $\begin{array}{c}\text { Pendapatan } \\
\text { Bulan }\end{array}$ \\
\hline 1 & I & $\begin{array}{l}\text { J1. Adam Malik, J1. Kapt. Tendean, J1. P. } \\
\text { Natadirja, J1. RE. Martadinata, J1. Raden } \\
\text { Patah, Jl. DP. Negara, J1. Padang Kemiling }\end{array}$ & 64 & $\begin{array}{l}\text { Rp.30.525.0 } \\
00\end{array}$ \\
\hline 2 & II & J1.S.Parman, J1.Mayjen Sutoyo, J1.Suprapto & 59 & $\begin{array}{l}\mathrm{Rp} 25.360 .00 \\
0\end{array}$ \\
\hline 3 & III & J1. Soeprapto Sebelah Kiri & 29 & $\begin{array}{c}\mathrm{Rp} \\
37.925 .000\end{array}$ \\
\hline 4 & VI & to Sebelah Kanan & 25 & $\begin{array}{l}\text { Rp.32.388.0 } \\
00\end{array}$ \\
\hline 5 & $\mathrm{~V}$ & J1. KZ. Abidin s/d PTM kota Bengkulu & 47 & $\begin{array}{l}\text { Rp.42.037.0 } \\
00\end{array}$ \\
\hline 6 & VI & Panorama kota Bengkulu & 153 & $\begin{array}{c}\text { Rp.113.667. } \\
500 \\
\end{array}$ \\
\hline 7 & VII & $\begin{array}{l}\text { J1.Jati, J1.Dempo, J1. Mahakam, J1.kapuas, } \\
\text { J1.Asahan, J1.Danau, J1.Meranti, J1.Merapi }\end{array}$ & 47 & $\begin{array}{l}\text { Rp. } 16.823 .0 \\
00\end{array}$ \\
\hline 8 & VIII & $\begin{array}{l}\text { Jl. Ahmad Yani, Pasar baru s/d Anggut } \\
\text { bawah }\end{array}$ & 56 & $\begin{array}{l}\text { Rp.29.975.0 } \\
00\end{array}$ \\
\hline 9 & IX & Pantai Panjang s/d Tapak paderi & 57 & $\begin{array}{l}\text { Rp.23.380.0 } \\
00\end{array}$ \\
\hline 10 & $\mathrm{X}$ & $\begin{array}{lr}\text { J1.Bangka,J1Kinibalu,Jl. } & \text { Jend } \\
\text { Sudirman,J1,Nusa Indah, J1. } & \text { Sedap } \\
\text { Malam,J1 MT Haryono,Jl.Flamboyan } & \\
\end{array}$ & 52 & $\begin{array}{c}\mathrm{Rp} . \\
24.747 .000\end{array}$ \\
\hline 11 & XI & Muara Bangkahulu & 23 & $\begin{array}{c}\text { Rp.8.665.00 } \\
0\end{array}$ \\
\hline 12 & $\mathrm{XII}$ & Basuki Rahmad s/d Jl. Bali & 13 & $\begin{array}{l}\text { Rp.4.780.00 } \\
0\end{array}$ \\
\hline
\end{tabular}

Sumber: Dinas Perhubungan Kota Bengkulu 2020

Standar Operasional Prosedur (SOP) yang dimaksud berkaitan dengan pembuatan Surat perintah tugas (SPT) parkir, permohonan lahan parkir baru, Surat perintah tugas (SPT) parkir merupakan pembeda juru parkir liar dan juru parkir yang terdaftar dalam Dinas Perhubungan. Ketentuan lainnya yang harus dipenuhi petugas parkir adalah seperti rompi parkir, topi parkir, kartu tanda pengenal dan peluit. Standar operasional prosedur (SOP) tersebut sudah ditercantum dalam tabel 2. Tentang standar pelayanan izin parkir. Ketaatan pelaksana kebijakan retribusi pelayanan parkir tepi jalan umum tepatnya di 
daerah Panorma, ini masih bersifat relatif. Maksud dari relatif itu adalah dalam hal non teknis seperti administrasi implementor tepatnya petugas parkir sudah memenuhi syarat yang telah di tentukan oleh Dinas Perhubungan, seperti adanya SPT parkir, selalu memberikan setoran parkir sesuai yang telah ditetapkan. Namun secara teknis di lapangan Dinas Perhubungan tidak menjamin pelaksanaan yang sesuai dengan prosedur yang telah ditetapkan. Pernyataan tersebut dikuatkan oleh fakta yang ada di lapangan, seperti adanya pihak ke tiga (3) selaku pengelola parkir. Hal tersebut dijelaskan oleh Bapak Hanafi dalam Yogi (2018:70) seorang juru parkir yang mengaku berkerja sama dengan pihak ke tiga.

"Saya sendiri pihak ke tiga (3) untuk menarik parkir, saya bagi hasil dengan pemilik SPT saya hanya menarik parkir dia (Pemilik SPT) yang menyetorkan ke Dishub"

Penemuan tersebut dibenarkan oleh pihak Dinas Perhubungan kota Bengkulu, Dinas Perhubungan menjelaskan ada beberapa zona parkir yang diserahkan pengelolaannya kepada pihak ke-3 yakni pihak CV Putra Wijaya. Pengelola, hal tersebut telah mengikuti standar operasional prosedur yang berlaku. Berdasarkan penelitian yang telah di lakukan Kepatuhan pelaksana kebijakan terhadap standar operasional Prosedur yang telah ditetapkan oleh Dinas Perhubungan kota Bengkulu berdasarkan Perda No. 07 Tahun 2011 di kota Bengkulu Secara Administratif sudah baik, karena pembuatan Surat perintah tugas (SPT) baik bagi juru parkir maupun titik parkir baru tidak ditemui masalah. Akan tetapi pelaksana kebijakan dalam hal ini petugas parkir secara teknis di lapangan masih banyak terjadi penyimpangan dari peraturan yang telah ditetapkan oleh Dinas Perhubungan Kota Bengkulu.

Subjek kebijakan parkir tepi jalan umum ini adalah pengguna parkir di tepi jalan umum dan tempat yang telah ditentukan oleh pihak Dinas Perhubungan. Sedangkan objek kebijakan parkir tepi jalan umum ini adalah penyediaan pelayanan parkir di tepi jalan umum. Adapun temuan di lapangan menunjukan petugas parkir yang menarik retribusi yang ada di depan ruko di sekitaran daerah Panorama tepatnya di seputaran Jalan 
Semangka. Akan tetapi temuan tersebut bukan pelanggaran karena masik kedalam subjek parkir yang di tentukan oleh Dinas Perhubungan. Dari observasi yang dilakukan peneliti di lapangan memang juru parkir di kota Bengkulu menegtahui besaran tarif dan sasaran parkir karena ada pengawasan yang dilakukan oleh pihak Dinas Perhubungan. pelaksanaan kebijakan retribusi pelayanan parkir di tepi jalan umum sudah sampai kepada sasaran yang telah ditentukan. Seperti yang tertuang pada Perda No. 07 Tahun 2011 kota Bengkulu pasal 3 dan 4 tentang subyek dan obyek parkir dan juga pasal 8 tentang tarif parkir. Dari peraturan menjadi acuan dari Dinas Perhubungan untuk membuat kebijakan - kebijakan yang membantu pelaksanaan Perda No. 07 Tahun 2011 kota Bengkulu

Kota Bengkulu memiliki Dari 652 titik dan dilihat dari segi pendapatan asli daerah (PAD) memang pendapatan dari sektor parkir ini memang masih kecil dari besaran Pendapatan Asli Daerah (PAD) kota Bengkulu. Dari studi pustaka yang peneliti lakukan didapati Pendapatan Asli Daerah kota Bengkulu sebesar 176 Miliar pada tahun 2017 seperti yang dimuat dalam Harianrakyatbengkulu.com pada 24 Oktober 2017 (harianrakyatbengkulu.com/ver3/2017/10/24/pad-kota-hanya-rp-176miliar diakses pada 02 Febuari 2018, Pukul 09.00) Dari informasi diatas menunjukan pendapatan asli daerah (PAD) kota Bengkulu pada tahun 2017 adalah Rp.176 miliar dan pendapatan dari sektor parkir tahun 2017 adalah 4,25 miliar. Dari sektor ekonomi memang belum berpengaruh siknifikan, akan tetapi dari segi sosial kebijakan retribusi pelayanan parkir cukup berpengaruh tepatnya bagi petugas parkir yang ada di Panorama. Seperti yang dijelaskan oleh bapak Tabrin dalam Yogi (2018:67) seorang petugas parkir Panorama menjelaskan bahwa:

"saya sudah tiga (3) tahun menjadi juru parkir disini, tiap bualan saya menyetor Rp.680.000 setiap bulannya. Sedikit berat jalaninya karena terkadang seoran naik pas perpanjangan SPT tapi itu cukup untuk pengasilan saya sitaiap bulannya"

Dari data yang didapat dalam penelitian Prasetyo (2013:83-84) jumah titik parkir pada tahun 2013 adalah sebesar 378 titik parkir dan 122 titik diantaranya ada di daerah Panorama. Sedangkan pada hasil penelitian 
peneliti tahun 2018 jumlah titik parkir meningkat menjadi 560 titik dan 140 diantranya ada di daerah Panorama, hal tersebut tentu berpengaruh karena dapat membuka lapangan kerja baru. Dalam kebijakan retribusi pelayanan parkir ini, informasi yang didapatkan sebelumnya menunjukan bahwa realisasi pendapatan asli daerah (PAD) dari sektor parkir ini adalah Rp.4,25 miliar dari target RP.5 miliar. Pernyataan tersebut dibenarkan dengan temuan peneliti pada tabel. 4. Tentang pendapatan parkir kota Bengkulu perbualan yang tidak mencapai Rp. 350.000.000. selain itu adanya temuan pihak ke tiga (3) di lapangan yang tidak tahu persis berapa setoran yang diserahkan kepada Dinas Perhubungan.

Dari hasil penelitian menunjukan bahwa perbedaaan hasil dalam pelaksanaan kebijakan retribusi pelayanan parkir di tepi jalan umum dengan program yang dirancang oleh Dinas Perhubungan kota Bengkulu berpedoman Perda No. 07 Tahun 2011 dikarenakan maih kurangnya potensi parkir yang ada di kota Bengkulu dan ketidaksesuaian di kota Bengkulu di karenakan dengan sikap implementor kebijakan yang tidak mengikuti aturan yang ada.

\section{PEMBAHASAN}

Analisis kebijakan retribusi parkir tepi jalan umum di daerah Panorama yang akan peneliti lakukan adalah terkait pemantauan kebijakan dengan menerangkan kepatuhan, pemeriksaan (Auditing), akuntansi dan eklpanasi terhadap implemantasi Kebijakan retribusi pelayanan parkir di tepi jalan umum daerah Panorama dengan yang berlandaskan Perda No. 07 Tahun 2011 kota Bengkulu.

\section{Kepatuhan (compliance)}

Kepatuhan yang dimaksud terkait tentang pelaksanaan kebijakan yang sesuai dengan standar dan prosedur yang ada. Menurut Dunn (2003) kepatuhan dalam pemantauan adalah terkait kesesuaian tindakan para pelaksana kebijakan dengan standar dan prosedur yang dibuat.

Dari hasil pengumpulan data yang dilakukan peneliti di Dinas Perhubungan kota Bengkulu dan kawasan parkir daerah Panorama, 
menerangkan bahwa standar dan prosedur yang dibuat sudah dijalankan sesuai Perda No. 07 Tahun 2011 kota Bengkulu oleh Dinas Perhubungan yang diwakili Unit Pelaksan Teknis Dinas Parkir Bengkulu. Pembuatan Surat Perintah Tugas (SPT) kawasan parkir dan petugas parkir dan penyerahan setoran parkir sesuai dengan Perda No. 07 Tahun 2011 kota Bengkulu Pasal 11 Ayat ke 3 yang berbunyi "Pemungutan retibusi yang diborongkan atau tidak dengan menggunakan Surat Ketetapan Retribusi Daerah Atau Dokumen Lain Yang Dipersamakan".

Pelaksanaan kebijakan retribusi parkir oleh petugas parkir di kota Bengkulu, secara administratif sudah sesuai dengan standar dan prosedur yang ada, yang dimaksud dari secara administratif adalah adanya Surat Perintah Parkir, dan membayar setoran parkir kepada Dinas Perhubungan. Akan tetapi dalam masalah teknis dilapangan masih ada yang terjadi seperti kuarangnya perlekanpan seperti kartu tanda pengenal, adanya pihak ke tiga (3) yang memungut reribusi. Pihak ke tiga (3) memang dibenarkan dalam Perda No. 07 Tahun 2011 kota Bengkulu pasal 14 Pemerintah dalam hal ini Dinas Perhubungan dapat menunjuk perusahaan atau kelompok tertentu untuk mengelola daerah parkir tersebut akan tetapi dalam hal ini berbeda karena menyalahgunaan Surat Perintah Tugas yang dimiliki oleh Petugas Parkir yang di serahkan kepada orang lain.

\section{Pemeriksaan (Auditing)}

Menurut Dunn (2003) Pemeriksaan (Auditing) dalam pemantauan kebijakan adalah sejauh mana sumberdaya dan pelayanan sampai kepada kelompok sasaran. Hasil pemantauan peneliti dari pengumpulan data yang dilakukan pada Dinas Perhubungan dan Zona Parkir kota Bengkulu, pelaksanaan kebijakan pelayanan parkir sudah sampai kepada target yang telah ditentukan seperti yang terjantum dalam Perda No. 07 Tahun 2011 kota Bengkulu pasal 9 yang menjelaskan bahwa "Retribusi yang terhutang dipungut di wilayah daerah tempat pelayanan parkir yang diselenggarankan ". Penelitian yang dilakukan peneliti menjawab latarbelakang masalah yang peneliti sajikan pada Sub Bab Latar Belakang di Bab I yang menerangkan tentang kontroversi pemungutan di depan ruko-ruko di beberapa zona 
parkir kota Bengkulu. Pemungutan retribusi tersebut termasuk hal yang diatur dalam kebijakan parkir, karena pada awal pembuatan surat perintah tugas (SPT) pemohon harus mengumpulkan surat ixin dari pemilik toko seperti yang di tercantun dalam gambar 1,2,3, danTabel 1. Selain kelompok sasaran, besaran tarif parkir juga sudah sesuai dengan yang tertera dalam pasal 8 Perda No 07 Tahun 2011 kota Bengkulu tentan skema besaran tarif parkir. Tarif parkir sesuai dengan kebijakan yang berlaku hal tersebut didukung oleh komunikasi yang baik dilakukan oleh Dinas Perhubungan selaku pelaksana dan pengawas kebijakan kepada petugas parkir selaku pelaksana pemungutan retribusi.

\section{Akuntansi}

Pelaksanaan kebijakan retribusi pelayanan parkir tepi jalan umum ini adalah mengenai penagurh sosial dan ekonomi yang menjadi dampak pelaksanaan kebijakan tersebut. Menurut Dunn (2003) Akutansi dalam pemantauan kebijakan adalah terkait informasi perubahan sosial dan ekonomi dari waktu ke waktu. Dari hasil pengumpulan data yang dilakukan oleh peneliti dalam segi ekonomi pelaksanaan kebijakan parkir ini tidak berdampak signifikan terhadap perekonomian kota Bengkulu dilihat dari pendapatannya yang masih dibawah 5 miliar pertahun, seperti tahun 2019 pendapatan asli daerah dari sektor parkir adalah 4,25 miliar dari total pendapatan asli daerah (PAD) kota Bengkulu tahun 2019.

Tetapi dalam segi sosial hal tersebut cukup berdampak mengingat jumlah titik parkir yang cukup banyak yakni 652 titik dari hasil penelitian yang dilakukan peneliti, jumlah terebut akan terus bertambah sejalan dengan potensi parkir di kota Bengkulu. Jumlah titik parkir yang lebih tinggi bisa berdampak pada penambah mata pencarian masyarakat di kota Bengkulu dan hal tersebut dapat mengatasi menimnya peluang kerja yang ada di Bengkulu.

\section{Eksplanasi}

Pelaksanaan suatu kebijakan tidaklah selalu sesuai dengan apa yang telah direncanakan, menurut Dunn (2003) Eksplansi dalam pemantauan 
kebijakan menjelaskan hasil - hasil kebijakan publik dan program berbeda. Dari hasil pengumpulan data yang peneliti lakukan perbedaan yang terjadi dalam kebijakan retribusi pelayanan parkir tepi jalan umum adalah target dan realisasi pendapatan dari sektor parkir yang berbeda yakni target Pendapatan asli daerah dari sektor parkir adalah 5 miliar pada tahun 2019 dan realisasinya adalah 4,25 miliar dari 652 titik parkir. Hal tersebut bisa terjadi dikarenakan potensi parkir yang ada dikota bengkulu hanya bisa mencapai hasil tersebut.

Daerah Panorama yang memiliki titik parkir terbanyak di kota Bengkulu yakni 153 titik parkir hanya bisa menyumbang Rp. 113.667.000 perbulan. Hal tersebut dirasa masih kurang maksimal karena jumlah titik parkir yangada didaerah Panorama melebihi 100 titik parkir. Dan pendapatan terendah berada pada zona 12 kampung bali dengan pendapatan Rp. 4.870 .000 dari 13 titik parkir.

\section{KESIMPULAN}

Berdasarkan hasil pemantauan kebijakan yang dilakukan peneliti dalam pembahasan yang telah disajikan tentang Monitoring kebijakan parkir tepi jalan umum di kota Bengkulu dapat diambil kesimpulan bahwa:

1. Pelaksanaan kebijakan retribusi pelayanan parkir tepi jalan umum oleh Dinas Perhubungan kota Bengkulu sudah sesuai dengan standar dan prosedur yang berpedoman pada Perda No. 07 Tahun 2011 tetapi masih ada ketidaksesuaian yang didapat dari hasil pelaksanaan kebijakan. Dalam pemeriksaan (Audit) kebijakan parkir yang dilaksanakan di kota Benhgkulu sudah sampai kepada kelompok sasaran seperti yang tertera dalam Pasal 9 dan Pasal 8 Perda No. 07 Tahun 2011. Dalam pemantauan dibidang Akuntansi, kebijakan retribusi pelayanan parkir tepi jalan umum berpengaruh pada kondisi sosial masyarakat kota Bengkulu. Dan dalam penjelasan Eksplanasi yang peneliti terangkan bahwa ketidak sesuaian kebijakan dari hasil yang di tentukan dalam Hal ini Pendapatan Asli Daerah dalam sektor pakir dikarenakan potensi parkir yang ada di kota Bengkulu belum bisa memenuhi target yang telah di tentukan. 
2. Faktor pendukung kebijakan retribusi pelayanan parkir tepi jalan umum di kota Bengkulu adalah adanya standar dan prosedur yang sudah jelas dan komunikasi yang dilakukan dengan baik oleh Dinas Perhubungan selaku Pelaksana Kebijakan. Dan faktor penghambat dari kebijakan tersebut adalah sarana dan sikap para pelaksana kebijakan yakni petugas parkir.

\section{DAFTAR PUSTAKA}

Agustino, Leo. 2008. Dasar-Dasar Kebijakan Publik. Bandung: CV. Alfabeta. Anwar, Faizal. 2015, Analisis Kebijakan Publik, Diktat Kuliah FISIPOL Universitas Muhammadiyah Bengkulu

Anggra, Sahya.2014. Kebijakan Publik. Pustaka Setia: Bandung

Arenawati. 2014, Adimistrasi Pemerintahan Daerah, Graha Ilmu: Yogyakarta

Dunn, William N. 20003, Pengantar Analisis Kebijakan Publik, Gajah Mada University Press :Yogyakarta

Indiahono, Dwiyanto.2009. Kebijakan publik berbasis Dynamic Policy Analisys, Gava Media: Yogyakarta

Moleong,J.Lay.2004. Metode Penelitian Kualitatif.Gramedia: Jakarta

Nugroho,Rian. 2003. Kebijakan Publik, Formulasi, Implementasi dan Evaluasi. Jakarta : Media Komputindo

Nugroho, Rianto. 2014, Metode Penelitian Kebijakan. Pustaka Pelajar: Yogyakata

Subarsono, AG. 2006. Analisis Kebijakan Publik: Konsep, Teori dan Aplikasi. Pustaka Pelajar : Yogyakarta

Sugiyono, 2011, Metode Penelitian Kuantitatif Kuaitatif Dan R\&D, Alfabeta: Bandung

Suharto, Edi.2008. Analisis Kebijakan Publik: Panduan Paktis Mengkaji Masalah Dan Kebijakan Sosial. Alfabeta: Bandung

Syafiie, Ibnu Kencana.2006.Sistem Administrasi Republik Indonesia(SANRI). Bumi Aksara : Jakarta

Winarno,Budi.2012. Kebijakan Publik : Teori, Proses dan Studi Kasus. Caps : Depok 


\section{Peraturan Perundang - Undangan :}

Undang - Undang Nomor 22 Tahun 2009 Tentang Lalu Lintas dan Angkutan Jalan.

Undang - Undang Nomor 23 Tahun 2014 Tentang Pemerintahan Daerah Undang - Undang Nomor 28 Tahun 2009 Tentang Pajak Daerah dan Retribusi Daerah.

Peraturan Daerah Kota Bengkulu Nomor 07 Tahun 2011 Tentang Retribusi Pelayanan Parkir Di Tepi Jalan Umum.

Peraturan Daerah Kota Bengkulu Nomor 10 Tahun 2016 Tentang Perubahan Nomenklatur SKPD Kota Bengkulu

\section{Jurnal dan Penelitian Ilmiah :}

Alfiansyah,Yogi.2018. Analisis Implementasi Kebijakan Retribusi Pelayanan Parkir Tepi Jalan Umum Daerah Panorama Kota Bengkulu. Universitas Muhammadiyah Bengkulu.Bengkulu.

Lukman, Dwi Jayanti.2015.Implementasi Kebijakan Perpakiran Di Kota Makassar.Makassar

Rahmad,Paisal.2014.Implementasi Kebijkan Parkir DiTepi Jalan Umum: Studi K Kasus jalan Pahlawan Pasar Segiri Kota Samarinda.Jurnal Ilmu Administrasi Negara Volume 4,Nomor 2: Samarinda

Rahmah,Syafia.2016.Evaluasi Terhadap Pengelolaan Parkir di Tepi Jalan Umum di Kawasan Simpang Lima Kota Semarang. Jurnal FISIP Universitas Dipenegoro: Semarang

Prasetyo, Endri.2014. Efektifitas Kebijakan Pemungutan Retribusi Parkir Di Kota Bengkulu. Bengkulu

\section{Daftar Referensi Media:}

“Retribusi Parkir di Protes”.2016.Di Akses pada 27 Oktober 2017 pukul 19.00 WIB . www.harianrakyatengkulu./ver3/2016/02/13/retribusi-parkirdiprotes/.

“Tanpa Karcis Setoran Parkir Rawan Korupsi ".5 Juli 2016.Rakyat Bengkulu "PAD Parkir Kota Bengkulu Teridikasi Bocor”.2016.Di akses Pada 20 Oktober 2017 pukul 17.00 WIB.ww.bengkuluekspress.com/pad-parkir-kotabengkulu-teridikasi- bocor/.

"PAD Kota Hanya 176 Miliyar" Harianrakyatbengkulu.com pada 24 Oktober 2017 diakses pada 02 Febuari 2018, Pukul 09.00 harianrakyatbengkulu.com/ver3/2017/10/24/pad-kota-hanya-rp176-miliar 